\title{
IMPLIKASI PERAN GANDA PEREMPUAN DALAM KEHIDUPAN KELUARGA DAN LINGKUNGAN MASYARAKAT
}

\author{
Ninin Ramadani \\ SMA Negeri 3 Cirebon \\ E-mail:nininramadani@yahoo.co.id
}

\begin{abstract}
This research background is about the double role of a woman who make batik that must be smart to devided her time for her family, works and also a part of society. This research use description of qualitative approach. The data was collected by observation, depth interview and documentation of studi. The finding result of this research are: (1) the general illustration of double role woman who makes batik as a housekeeper, as makes batik, as a member of PKK and a part of Majelis Ta'lim. (2) there are two part problem which is come to woman who makes batik, internal and external. For instance the problem based on internal such as feel tired, feel bored and the problem from external is limited of time. (3) there are positive and negative impact for woman who makes batik. The advantages to woman who make batik, it can helpful her family.
\end{abstract}

Key word: double role of women, family life, the society.

\begin{abstract}
ABSTRAK
Penelitian ini dilatarbelakangi oleh peran ganda perempuan pengrajin batik yang harus pintar dalam membagi waktu antara keluarga, pekerjaan, dan sebagai anggota masyarakat. Penelitian ini menggunakan pendekatan kualitatif deskriptif. Teknik pengumpulan data dilakukan dengan observasi, wawancara mendalam, dan studi dokumentasi. Temuan hasil penelitian terungkap bahwa: (1) Gambaran umum peran ganda pada perempuan pengrajin batik yaitu peran sebagai ibu rumah tangga, peran sebagai pengrajin batik dan peran sebagai anggota masyarakat dengan menjadi anggota PKK dan anggota Majelis Ta'lim. (2) Kendala yang dirasakan perempuan pengrajin batik dalam menjalankan semua perannya berasal dari internal dan eksternal. Kendala internal yaitu lelah fisik, lelah mental, jenuh, malas dan kendala eksternal yaitu adanya keterbatasan waktu. (3) Dampak yang terjadi pada perempuan pengrajin batik dalam menjalankan peran gandanya berdampak positif dan negatif. Dampak positifnya akan memperoleh penghasilan sehingga dapat membantu perekonomian keluarga, adanya kerja sama antara suami, isteri dan
\end{abstract}


anak dalam menyelesaikan tugas rumah tangga, meningkatkan keterampilan dalam membatik, memperluas lingkungan sosial karena mengikuti kegiatan di masyarakat, sedangkan dampak negatifnya berkurangnya waktu untuk keluarga.

Kata Kunci: Peran Ganda Perempuan, Kehidupan Keluarga, Lingkungan Masyarakat

\section{PENDAHULUAN}

Bekerja merupakan hal yang paling utama dalam memenuhi kebutuhan keluarga. Selain itu bekerja juga merupakan suatu kewajiban untuk memenuhi kebutuhan keluarga. Dalam suatu rumah tangga bekerja itu merupakan suatu kewajiban karena jika di dalam rumah tangga, anggota keluarga tidak bekerja maka mereka tidak akan memenuhi kebutuhannya.

Dalam keluarga yang mencari nafkah atau bekerja merupakan kewajiban dari kepala keluarga. Pada dasarnya dari zaman ke zaman kepala keluarga mempunyai kewajiban untuk memenuhi kebutuhan keluarganya yaitu dengan cara bekerja. Tidaklah heran jika kepala rumah tangga banting tulang setiap hari dan selalu pulang larut malam itu dikarenakan hanya untuk memenuhi kebutuhan keluarganya. Seiring dengan perkembangan zaman peranan dari laki-laki yang bekerja sekarang sudah berubah yaitu sang istri atau perempuan ikut dalam bekerja. Begitu pula menurut Othman (2015) (terjemahan):

Peran perempuan telah berubah selama beberapa dekade dalam membantu diri mereka sendiri dan orang yang mereka cintai dalam mencapai kemakmuran bersama dan meningkatkan status ekonomi sosial mereka sebagai cara untuk melarikan diri dari kemiskinan dan kerentanan. (hlm 1044)
Peranan perempuan pada zaman sekarang berbeda dengan zaman dahulu dimana pada zaman dahulu perempuan hanya boleh bekerja di rumah saja, berbeda dengan zaman sekarang dengan adanya keberhasilan gerakan emansipasi perempuan, perempuan dibolehkan bekerja di luar rumah dan sering terlibat dalam berbagai kegiatan. Hal ini sudah memperlihatkan bahwa peranan perempuan tidak hanya di dalam rumah saja melainkan juga di luar rumah. Biasanya yang menjadi tulang punggung keluarga itu adalah suami tetapi dengan berkembangnya zaman, perempuan juga bekerja dan berperan untuk kebutuhan ekonomi keluarga. Pada saat ini perempuan tidak lagi berperan menjadi ibu rumah tangga saja tetapi sudah berperan di berbagai bidang. Alasan dari perempuan bekerja diluar rumah tidak asing lagi yaitu karena tuntunan kebutuhan hidup bagi keluarga. Meskipun seorang suami berkewajiban mencari nafkah, hal ini tidak menutup kemungkinan seorang istri untuk bekerja sebagai penambah penghasilan keluarga. Selain alasan perempuan bekerja untuk mencari nafkah terdapat alasan lain yaitu supaya perempuan dapat dihargai dan diakui keberadaanya di lingkungan masyarakatnya.

Seorang perempuan atau isteri yang bekerja di luar rumah bisa disebut dengan perempuan berperan 
ganda, peran ganda merupakan perempuan yang mempunyai dua pekerjaan yang dilakukan dengan satu waktu yaitu bekerja di rumah dan di luar rumah. Dalam pemenuhan kebutuhan keluarga yang sejahtera perempuan atau isteri setiap hari harus berusaha supaya semua perannya baik menjadi ibu rumah tangga dan juga mencari nafkah itu bisa berjalan dengan baik dan seimbang. Karena itu perempuan harus bisa mengatur waktunya sehingga dapat dilaksanakan dengan baik dan seimbang. Dalam hal ini perempuan yang mempunyai peran ganda pasti memiliki kendalakendalanya dalam melaksanakan pekerjaannya. Biasanya kendala yang dihadapi oleh perempuan yang bekerja di luar rumah adalah pekerjaan sebagai ibu rumah tangga akan terbengkalai dan kurangnya pengasuhan kepada anak-anaknya. Dalam hal ini walaupun perempuan diperbolehkan untuk bekerja di luar rumah, perempuan harus bisa mengatur waktu untuk bekerja sebagai ibu rumah tangga yang baik dan juga bekerja di luar rumah sehingga pemenuhan kebutuhan keluarga tidak terbengkalai.

Perempuan mempunyai peran dan kedudukannya baik sebagai isteri, ibu, pekerja maupun anggota masyarakat dimana ia tinggal. Peran perempuan di dalam keluarga sendiri terbagi menjadi dua yaitu sebagai isteri dan juga sebagai ibu bagi anakanaknya. Peran perempuan sebagai isteri tugasnya melayani suami sedangkan peran perempuan sebagai ibu yaitu melahirkan anak, merawat, memelihara dan juga mengayomi anggota keluarganya. Perempuan yang mempunyai pekerjaan di luar rumah juga mempunyai perannya sendiri yaitu dia mempunyai tanggung jawab pada pekerjaan yang dia miliki. Peran yang terakhir adalah perempuan sebagai anggota masyarakat, selain perempuan itu menjadi ibu rumah tangga kemudian bekerja disamping keduanya mereka juga mempunyai peran di lingkungan masyarakatnya tujuannya supaya perempuan diakui keberadaannya sebagai anggota masyarakat dimana ia tinggal.

Berbicara mengenai perempuan yang bekerja atau perempuan yang mempunyai peran ganda pasti mereka memiliki konflik peran. Konflik peran dapat diartikan dimana seseorang yang memiliki peran bertentangan dengan peran lainnya. Dalam hal ini konflik yang dialami oleh seorang perempuan yang mempunyai peran ganda, dimana ia mempunyai peran sebagai ibu dan juga mempunyai peran sebagai pekerja. Kedua peran tersebut pasti memiliki pertentangan. Di satu sisi, perempuan mempunyai peranan di dalam keluarganya yaitu melayani suaminya, mendidik anak-anaknya dan juga menjadi ibu rumah tangga yang baik tetapi, di sisi lain perempuan juga mempunyai tanggung jawab dengan pekerjaan yang dia miliki.

Ketika seorang perempuan yang sudah mempunyai keluarga memutuskan untuk bekerja, pasti terdapat resiko-resikonya yang harus mereka hadapi khususnya berkaitan 
dengan berkurangnya waktu yang mereka miliki untuk keluarganya. Perempuan yang bekerja sebagai pengrajin batik pasti seringkali menghadapi dilema terkait dengan keluarga dan juga pekerjaannya. Di satu sisi, perempuan mempunyai peran yang penting didalam keluarganya yaitu dengan menjadi ibu rumah tangga yang baik untuk mendidik anak-anaknya dan juga melayani suaminya, tetapi di sisi lain perempuan juga mempunyai tanggung jawab terhadap pekerjaan yang dia punya. Maka dari itu perempuan yang bekerja mempunyai dilemanya sendiri mengenai pembagian waktu di keluarga dan juga pekerjaannya. Tetapi ada juga dilema lainnya yaitu perempuan ingin berusaha supaya mereka diakui keberadaanya di lingkungan masyarakatnya.

Pada kenyataannya, menjadi seorang pekerja itu tidak mudah, mereka harus menjalankan semua peran gandanya. Akan tetapi, dengan segala peran yang mereka miliki, dengan jam kerja yang padat, menuntut mereka untuk tetap berpartisipasi dan bertanggung jawab dalam melaksanakan peranannya baik sebagai ibu rumah tangga maupun sebagai anggota masyarakat dalam kegiatan PKK dan Majelis Ta'lim. Berbagai peran yang harus dijalani seseorang ibu sekaligus sebagai pekerja, membuat mereka jarang bahkan susah untuk berkumpul dengan keluarganya, serta berinteraksi dengan masyarakat. Namun masih ada perempuan pengrajin batik yang dapat menyeimbangkan peran gandanya dengan meluangkan waktu untuk mengurus rumah tangganya, serta ikut dalam kegiatan di masyarakat yaitu PKK dan Majelis Ta'lim. Ketika manusia hidup di dalam lingkungan masyarakat, maka ia harus bersosialisasi dengan masyarakat sekitar untuk dapat mengembangkan hidupnya baik di keluarga dan masyarakat.

Berdasarkan latar belakang penelitian yang telah dijabarkan, mengenai segala peran yang dimiliki perempuan pekerja terutama pada perempuan pengrajin batik membuat mereka masih bisa melakukan perannya sebagai ibu rumah tangga dan sebagai anggota masyarakat yaitu terlibat dalam kegiatan PKK dan Majelis Ta'lim, sehingga peneliti memfokuskan kepada gambaran umum peran ganda perempuan pada perempuan pengrajin batik. Dalam melakukan berbagai peran, perempuan memiliki kendala sendiri dalam melakukan semua perannya dan peneliti juga tertarik mengkaji kendala perempuan berperan ganda pada perempuan pengrajin batik, serta peneliti juga tertarik mengkaji mengenai dampak yang dirasakan pada perempuan pengrajin batik. Maka, penulis tertarik untuk melakukan penelitian lebih mendalam dengan mengambil judul tentang "Implikasi Peran Ganda Perempuan dalam Kehidupan Keluarga dan Lingkungan Masyarakat (Studi Deskriptif pada Perempuan Pengrajin Batik di desa Trusmi kecamatan Plered Kabupaten Cirebon)". 


\section{METODE}

Penelitian ini menggunakan pendekatan kualitatif deskriptif. Pendekatan kualitatif digunakan dalam penelitian ini dikarenakan yang diteliti dalam penelitian ini merupakan gambaran peran ganda perempuan dalam kehidupan keluarga dan lingkungan masyarakat, sehingga dapat mendeskripsikan, menguraikan, dan mengeksplorasi secara mendalam tentang permasalahan yang dibahas mengenai gambaran umum peran ganda perempuan, kendala perempuan berperan ganda dan dampak perempuan berperan ganda dalam kehidupan keluarga dan lingkungan masyarakat. Selain itu, pendekatan kualitatif deskriptif lebih efektif digunakan dalam penelitian ini, karena dalam teknik pengumpulan datanya efektif untuk mendapatkan data dari informan.

Informan dalam penelitian ini berjumlah 15 informan, yaitu 5 orang perempuan pengrajin batik, 4 orang suami dari perempuan pengrajin batik, 5 orang anak dari perempuan pengrajin batik, dan 1 orang kader PKK. Penelitian ini dilakukan di desa Trusmi Kecamatan Plered Kabupaten Cirebon. Pemilihan daerah penelitian dikarenakan di daerah tersebut terdapat banyak kaum perempuan yang menjadi pengrajin batik.

Teknik pengumpulan data yang digunakan peneliti meliputi observasi, wawancara, studi dokumentasi, dan studi literatur. Teknik analisis data menggunakan data reduksi (data reduction), penyajian data (data display), dan kesimpulan (conclusion drawing/verifiying). Data yang diperoleh akan diuji keabsahannya menggunakan teknik triangulasi sumber data dan teknik triangulasi pengumpulan data.

\section{HASIL DAN PEMBAHASAN}

Gambaran Umum Peran Ganda Perempuan dalam Kehidupan Keluarga dan Lingkungan Masyarakat

Berbicara mengenai peran ganda, perempuan pengrajin batik ini merupakan perempuan yang mempunyai peran ganda. Mereka bekerja di sektor domestik dan sektor publik. Peran mereka di bidang domestik antara lain mencuci, memasak menyiapkan makan, meyiapkan keperluan suami dan anak serta mengantarkan anak ke sekolah. Sedangkan peran di bidang publik yaitu pekerja sebagai pengrajin batik dan sebagai anggota masyarakat dengan mengikuti pengajian. Semua pekerjaan tersebut dilakukan dalam satu waktu dan perempuan yang mempunyai peran ganda harus bisa membagi waktunya antar pekerjaan di dalam rumah maupun pekerjaan di luar rumah sebagai pengrajin batik dan sebagai anggota masyarakat. Hampir semua perempuan pengrajin batik ini mengikuti kegiatan masyarakatnya seperti mengikuti pengajian, menjadi anggota PKK dan kegiatan masyarakat lainnya.

Setiap paginya perempuan pengrajin batik ini memanfaatkan waktunya untuk menjalankan perannya sebagai ibu rumah tangga terlebih dahulu sebelum menjalankan 
perannya sebagai pengrajin batik. Pekerjaan tersebut seperti mencuci, memasak, menyiapkan makan untuk suami dan anak serta mengantarkan anak ke sekolah. Setelah semua peran di rumah itu selesai barulah mereka pergi untuk bekerja sebagai pengrajin batik. Pernyataan ini sejalan dengan penelitian Siregar (2007, Vol. 02, No. 01) yang mengemukakan:

Disamping mempersiapkan diri untuk berangkat kerja, ia juga harus mengatur rumah tangganya seperti; mempersiapkan keperluan suami yang akan pergi bekerja, memperhatikan anak-anak yang akan pergi ke sekolah, adalah tugas seorang istri sebagai ibu rumah tangga. Mempersiapkan sarapan pagi juga merupakan tugas rutin seorang ibu rumah tangga, tanpa terkecuali apakah ia seorang pekerja atau tidak. (hlm. 12)

Jadi pada intinya setiap perempuan yang bekerja ia juga harus terlebih dahulu mengurus kebutuhan rumah tangganya seperti memasak, mencuci serta mengurus keperluan yang dibutuhkan oleh suami dan juga anak mereka.

Selama enam hari dalam satu minggu perempuan pengrajin batik ini bekerja yang membutuhkan waktu lama yaitu 8 jam perharinya yang dimulai pukul 08:00-16:00 WIB. Mereka dengan giat bekerja sebagai pengrajin batik, alasan perempuan pengrajin batik ini ikut serta dalam bekerja adalah karena tuntutan ekonomi yang mengharuskan mereka ikut serta dalam bekerja. Suami mereka juga bekerja tetapi penghasilan yang diberikan masih kurang untuk memenuhi kebutuhan sehari-harinya. Hal ini sejalan dengan pernyataan Mardikanto, 1990 yang mengemukakan:

Terdapat faktor pendorong isteri untuk berkakir, yaitu alasan ekonomi untuk menambah pendapatan keluarga, terutama jika penghasilan suami relatif kecil, atau isteri memiliki keunggulan tertentu sehingga merasa lebih efisian jika waktunya digunakan untuk berkarir dari pada melakukan pekerjaan di rumah. (hlm. 89)

Peneliti menganalisis bahwa perempuan pengrajin batik ini mempunyai alasan mengapa mereka ikut bekerja yaitu untuk membantu suami dalam mencari penghasilan sehingga kebutuhan ekonomi terpenuhi, karena penghasilan yang suami berikan belum cukup untuk keperluan sehari-harinya.

Selain peran perempuan sebagai ibu rumah tangga dan sebagai pengrajin batik, perempuan juga mempunyai peran di lingkungan masyarakatnya.

Perempuan pengrajin batik ini mengikuti kegiatan masyarakat yaitu ada yang berpartisipasi dalam kegiatan PKK dengan mengikuti salah satu kegiatannya yaitu pengajian dan ada juga yang berpartisipasi sebagai anggota majelis ta'lim dengan mengikuti kegiatan pengajian. Pengajian yang dilakukan oleh perempuan pengrajin batik ini diadakan setiap satu minggu sekali pada malam hari. Ada yang mengikuti pada malam senin dan ada juga yang mengikuti pada malam jumat. 
Kegiatan pengajian ini dilakukan setelah isya sampai pukul 23:00.

Setelah melihat beberapa peran yang dimiliki oleh perempuan pengrajin batik ini, mereka bisa di bilang memiliki beban ganda. Hal ini sejalan dengan pernyataan Mardikanto, 1990, hlm. 31 “...bahwa perempuan yang melakukan pengasuhan anak dan melakukan pekerjaan nafkah itu disebut dengan beban ganda, beban ganda berpengaruh terhadap waktu isteri". Dapat dilihat pada pembahasan sebelumnya bahwa perempuan pengrajin batik memiliki waktu untuk melakukan peran sebagai ibu rumah tangga selama 8 jam, peran sebagai pengrajin batik selama 8 jam perharinya, belum lagi saat mereka melakukan kegiatan di masyarakat yang berperan sebagai anggota masyarakat yang diadakan satu minggu sekali selama 4 jam. Peran yang dilakukan oleh perempuan pengrajin batik ini merupakan beban ganda karena mereka melakukan sendiri. Terkadang suami dan anak mereka ikut membantu dalam pekerjaan rumah tangga. Mardikanto, 1990, hlm. 31 "...suami melakukan pekerjaan rumah tangga hanya sedikit saja atau bahkan relatif sama". Para suami terkadang meluangkan waktu luangnya untuk melakukan pekerjaan rumah tangga saat isteri bekerja di luar yaitu memasak pada siang harinya dan terkadang suami ikut membantu anak dalam mengerjakan tugas sekolahnya. Walaupun perempuan pengrajin batik ini dikatakan sebagai perempuan yang mempunyai beban ganda dan terkadang merasa lelah dengan melakukan semua perannya, mereka tetap bersikap biasa saja karena mereka sudah terbiasa dengan semua peran yang dimilikinya. Menurut Mardikanto, 1990 menyatakan bahwa:

\begin{tabular}{|c|}
\hline $\begin{array}{l}\text {...dunia perempuan } \\
\text { sersifat "rutin" itu } \\
\text { menempatkannnya } \\
\text { keadaan untuk memanf } \\
\text { keterampilannya } \\
\text { nelepaskan sebagian } \\
\text { vaktu luangnya. Tetapi } \\
\text { sihak, juga mencerr } \\
\text { sebagaian besar pere } \\
\text { lang ternyata memp } \\
\text { repuasan dari penyel } \\
\text { ugas-tugas rumah ta } \\
\text { hlm. 30) }\end{array}$ \\
\hline
\end{tabular}

Pada dasarnya walaupun perempuan bekerja dari pagi hingga sore hari mereka tetap bisa membagi waktunya untuk menjalankan peranperan lainnya. Sebelum berangkat bekerja mereka melakukan tugas rumah tangga terlebih dahulu kemudian setelah peran itu selesai mereka langsung berangkat untuk bekerja, serta dalam satu minggu sekali mereka melakukan perannya sebagai anggota masyarakat dengan mengikuti pengajian yang di mulai setelah isya sampai pukul 23:00 WIB. Hal ini juga di perkuat dengan adanya pernyataan menurut penelitian dari Siregar (2007, hlm. 12) "seorang ibu yang bekerja tentu mempunyai waktu yang sangat terbatas. Disamping ia bekerja di sektor publik, ia harus menyisihkan waktu untuk mengurus rumah tangganya". Perempuan pengrajin batik ini mempunyai waktu yang terbatas dalam melakukan semua perannya tetapi mereka dapat 
membagi waktunya supaya semua peran yang dimilikinya dapat berjalan dengan baik dan seimbang. Lain halnya menurut Salaa (2015, Vol. 15 No. 08, hlm. 15) yang mengungkapkan bahwa "peran ibu rumah tangga yang bekerja di luar sebagai pencari nafkah ternyata mereka tidak pernah meninggalkan tugas dan tanggung-jawabnya sebagai seorang isteri dan sebagai seorang ibu dalam keluarga-nya". Dengan begitu, kondisi perempuan pengrajin batik yang sibuk dengan pekerjaanya, mereka tetap berupaya untuk memperhatikan suami dan anaknya.

Dalam pengambilan keputusan, semua keputusan sebenarnya ada pada suami. Ketika isteri memiliki keinginan untuk berperan di lingkungan publik mereka harus meminta izin terlebih dahulu kepada suami, sama halnya dengan para perempuan pengrajin batik ini. Suami perempuan pengrajin batik ini sangat memberi dukungan kepada isterinya untuk bekerja karena memiliki alasannya yaitu keperluan keluarga tidak hanya untuk memberi makan saja melainkan harus memenuhi kebutuhan sehari-harinya seperti membelikan anak jajan, membayar biaya sekolah serta keperluan rumah tangga lainnya. Selain dukungan untuk bekerja, para suami juga memberikan dukungan kepada isteri untuk mengikuti kegiatan pengajian. Alasan mengapa para suami memberi izin kepada perempuan pengrajin batik untuk mengikuti pengajian ini karena menurut para suami, pengajian itu merupakan hal yang positif supaya para perempuan ini bisa lebih dekat dengan Tuhan dan dapat memberikan pengetahuan yang lebih mengenai agama. Hal lain, saat isteri berada di rumah, mereka mengerjakan semua seluruh pekerjaan rumah tangga dengan baik.

Setelah melihat jawaban pada temuan di atas yang menjawab bahwa perempuan pengrajin batik ini memiliki peran yang lebih dari satu dan semua peran tersebut harus dijalankan dengan seimbang. Peranperan yang dijalankan oleh perempuan ini adalah peran sebagai ibu rumah tangga, peran sebagai pengrajin batik dan peran sebagai anggota masyarakat. Semua peran tersebut dikatakan sebagai fungsi manifest. Merton (dalam Poloma, 2013, hlm. 37) "yaitu fungsi manifest itu merupakan fungsi yang nyata". Peran-peran yang dimiliki oleh perempuan pengrajin batik ini merupakan fungsi yang nyata yaitu fungsi dari peran perempuan yang semestinya.

\section{Kendala Perempuan Berperan Ganda dalam Kehidupan Keluarga dan Lingkungan Masyarakat}

Kendala yang dirasakan oleh perempuan pengrajin batik ini terbagi menjadi dua yaitu kendala pada diri perempuan itu sendiri (intern) dan kendala dari luar (extern). Kendala pada diri sendiri (intern) seperti lelah fisik dan lelah mental, jelas semua orang pasti memiliki rasa yang sama dalam melakukan peran yaitu lelah fisik dan apalagi yang dirasakan oleh para perempuan pengrajin batik ini. 
Jika mental mereka kurang maka emosi mereka tidak akan stabil dan akan terjadi hubungan yang kurang baik bagi anggota keluarga lainnya. Mereka sebelum bekerja sebagai pengrajin batik terlebih dahulu harus menjalankan perannya sebagai ibu rumah tangga dengan menjalankan tugasnya seperti memasak, mencuci, menyiapkan keperluan suami serta anak dan mengurus rumah tangga. Kemudian setelah peran sebagai ibu rumah tangga itu selesai mereka langsung bersiap untuk berangkat bekerja sebagai pengrajin batik. Setelah peran sebagai ibu rumah tangga selesai, mereka berangkat ke sanggar untuk bekerja sebagai pengrajin batik yang memakan waktu 8 jam perhari yang dimulai pukul 08:00-16:00 WIB. Kemudian setelah pekerjaan di tempat kerja selesai perempuan pengrajin batik ini pulang menuju rumahnya dan melakukan kembali perannya sebagai ibu rumah tangga. Hal inilah yang mereka rasakan setiap harinya kecuali pada hari minggu. Mereka merasa lelah dengan menjalankan dua peran tersebut tetapi mereka harus lebih profesional dalam menjalankan tugasnya. Selain kedua peran tersebut, perempuan pengrajin batik juga mempunyai peran sebagai anggota masyarakat yaitu dengan mengikuti kegiatan masyarakatnya seperti pengajian. Pengajian ini dilakukan hanya satu minggu sekali yang dimulai setelah isya hingga hampir tengah malam. Hal inilah yang menyebabkan adanya kendala pada diri perempuan pengrajin batik saat menjalankan ketiga peran tersebut yaitu lelah fisik dan mental. Tetapi dengan sebaik mungkin mereka harus pintar-pintar dalam membagi waktunya walaupun mereka merasakan lelah yang tidak terhingga. Semua manusia pasti akan merasakan lelah fisik maupun mental termasuk pada perempuan pengrajin batik ini, semua peran harus bisa dijalankan dengan baik. Dalam menjalankan semua peran mereka juga akan merasakan rasa jenuh dan malas untuk menjalankan semua perannya.

Kendala lainnya adalah dari luar (extern), kendala ini bisa terjadi dari lingkungan keluarganya, tempat kerjanya dan lingkungan masyarakatnya. Kendala pertama ada di keluarga yaitu perempuan merasa takut jika kebutuhan keluarga takut tidak terpenuhi. Perempuan harus lebih pintar-pintar dalam membagi waktunya saat berada di dalam rumah maupun saat mereka bekerja dan juga peran perempuan pengrajin batik sebagai seorang ibu, harus tetap dijalankan sebaik-baiknya oleh mereka karena mereka merupakan perempuan yang mempunyai peran ganda. Kendala kedua yaitu adanya ketakutan di tempat kerjanya jika mereka melakukan kesalahan atau tidak mengikuti aturan yang sudah di tetapkan oleh atasannya mereka takut akan di keluarkan dari pekerjaan tersebut. Jika perempuan ini melakukan kesalahan dan di keluarkan dari pekerjaannya mereka bingung akan mendapatkan uang dari mana lagi selain sebagai pengrajin batik karena mereka hanya 
mempunyai keterampilan membatik dan pasti jika mereka di keluarkan dari pekerjaannya kebutuhan sandang dan pangan tidak akan terpenuhi. Kendala terakhir yang mereka rasakan adalah jika tidak pintar-pintar dalam membagi waktu pasti semua peran tidak akan berjalan dengan baik. Maka dari itu perempuan pengrajin batik ini harus lebih pintar dalam membagi waktunya yaitu saat mereka menjalankan peran sebagai ibu rumah tangga, peran sebagai pengrajin batik dan peran sebagai anggota masyarakat. Sehingga jika mereka pintar dalam membagi waktunya maka semua peran yang mereka miliki tidak akan terabaikan. Dalam menjalankan setiap perannya selain perempuan itu memiliki kendala mereka pasti merasakan adanya konflik dalam peran ganda tersebut. Konflik peran ganda muncul apabila perempuan merasakan ketegangan antara peran pekerjaan dengan peran keluarga. Hal ini juga diperkuat dari pernyataan dari Greenhaus dan Beutell (dalam Indriyani, 2009) ada tiga macam konflik peran ganda yaitu:

1. Time-based conflict. Waktu yang dibutuhkan untuk menjalankan salah satu tuntutan (keluarga atau pekerjaan) dapat mengurangi waktu untuk menjalankan tuntutan yang lainnya (pekerjaan atau keluarga)

2. Strain-based conflict. Terjadi tekanan dari salah satu peran mempengaruhi kinerja peran lainnya.

3. Behavior-based conflict. Berhubungan dengan ketidaksesuaian antara pola perilaku dengan yang diinginkan oleh kedua bagian (pekerjaan atau keluarga). (hlm.16)

Berdasarkan pendapat di atas, penulis menganalisis bahwa konflik yang dialami oleh perempuan pengrajin batik yaitu time-based conflict, strain-based conflict, dan behavior-based conflict. Pada timebased conflict, berkurangnya waktu perempuan pengrajin batik untuk bermain bersama anak saat jam kerja. Strain-based conflict, pada konflik ini perempuan pengrajin batik merasa takut jika mereka melakukan kesalahan di pekerjaannya mereka akan mendapatkan sanksi, yaitu kehilangan pekerjaan dan jika mereka kehilangan pekerjaannya, kebutuhan sehari-hari akan berkurang. Behavior-based conflict, perempuan pengrajin batik pada intinya harus bisa pintar dalam mengatur waktu yang mereka miliki sehingga semua peran yang dimilikinya dapat berjalan dengan baik dan seimbang.

\section{Dampak Perempuan Berperan Ganda dalam Kehidupan Keluarga dan Lingkungan Masyarakat}

Menurut Kusumawati (2012, Vol. 04, No. 02) "perempuan dengan peran ganda, memiliki waktu domestik dan waktu publik yang berdampak dalam kehidupannya". Semua peran yang dijalankan oleh perempuan pengrajin batik ini tentu saja akan merasakan dampak, baik itu dampak yang dirasakan oleh perempuan itu sendiri, dampak yang dirasakan oleh suami dan juga 
dampak yang dirasakan oleh anak dari perempuan pengrajin batik tersebut. Dampak sendiri terbagi menjadi dua yaitu dampak positif dan dampak negatif.

Dampak positif yang dirasakan oleh perempuan pengrajin batik saat bekerja di luar rumah dan menjadi anggota masyarakat dengan mengikuti pengajian ini adalah yang pertama dengan bekerja mereka akan mendapatkan penghasilan dan dapat membantu perekonomian keluarga. Mereka bekerja mulai pagi hari hingga sore hari hanya untuk mendapatkan upah untuk memenuhi kebutuhan sehari-hari keluarganya. Yang kedua meningkatkan keterampilan membatik, walaupun semua perempuan pengrajin batik ini sudah bisa dikatakan pintar dalam membatik perempuan ini masih merasa kurang dengan keterampilan membatiknya saat ini. Maka dari itu perempuan pengrajin batik sampai saat ini masih tetap bekerja sebagai pengrajin batik supaya keterampilan membatiknya dapat lebih terasah kembali. Dampak positif yang ketiga, saat mengikuti pengajian yaitu merasa lebih dekat dengan Tuhan dan menambah pengetahuan mengenai agama serta hubungan dengan masyarakat sekitar menjadi lebih baik lagi dan menjadi lebih dekat lagi dan tali silahturahmi tetap terjaga dengan masyarakat, selalu dapat berkomunikasi dengan masyarakat, menambah pergaulan, mempererat ikatan saudara dengan yang lainnya karena anggota dari pengajian ini tidak hanya tetangga sekitarnya saja melainkan warga dari desa lain. Kemudian selain dampak positif yang dirasakan oleh perempuan pengrajin batik ini ada juga dampak negatif dari peran yang dilakukannya yaitu yang pertama ibu merasa lelah dengan melakukan berbagai peran. Semua orang jelas merasa lelah ketika mereka melakukan peran yang lebih dari satu, waktu yang dimiliki oleh perempuan yang bekerja untuk beristirahat pun juga akan berkurang dengan harus menjalankan dengan baik peran yang dimilikinya. Dampak negatif yang kedua adalah waktu yang dimiliki untuk suami dan juga anak akan berkurang, selain berkurangnya waktu perempuan itu untuk beristirahat waktu yang ia miliki untuk berkumpul bersama suami dan anak pun juga pasti akan berkurang. Karena keterbatasan waktu yang dimilikinya mereka bekerja dari pagi hingga sore hari dan waktu untuk suami dan anak hanya sekedar mengobrol hanya dilakukan saat sore hari dan juga hari minggu yaitu hari dimana perempuan pengrajin batik ini libur.

Dampak lainnya juga dirasakan oleh suami perempuan pengrajin batik ini. Dampak positifnya yaitu ketika perempuan bekerja otomatis akan membantu perekonomian keluarga. Karena sebagian dari suami perempuan pengrajin batik hanya bekerja sebagai wiraswasta yang memiliki penghasilan tidak banyak. Saat perempuan mengikuti kegiatan masyarakat dengan mengikuti pengajian menurut suami pengrajin batik ini, itu merupakan hal yang positif sehingga dapat 
mendekatkan diri pada Tuhan dan mendapatkan teman selain di teman kerja serta tali silaturahmi dengan masyarakat lain akan berjalan dengan baik. Dampak negatifnya adalah berkurangnya waktu yang dimiliki untuk suami dan juga isteri. Semua pasangan suami isteri pasti akan mengharapkan hubungan yang lebih intim tetapi jika semua pasangan suami isteri bekerja otomatis hubungan intim mereka akan berkurang.

Dampak terhadap anak, setiap anak pasti akan merasakan dampak ketika ayah dan juga ibu mereka ikut serta dalam bekerja. Terutama ibu, ibu merupakan seseorang yang paling dekat dengan anaknya. Banyak peran yang harus dilakukan oleh ibu untuk anaknya. Situasi ibu yang bekerja menjadi perempuan pengrajin batik, terkadang menyadari kurangnya memberikan waktu untuk bersama anaknya hanya untuk sekedar mengobrol, tetapi dengan keterbatasan waktu tersebut, menjadikan mereka menggunakan waktu yang ada untuk memanfaatkan sebaik-baiknya untuk mengurus, mengasuh, mendidik, serta mencurahkan kasih sayangnya kepada anak. Hal ini sejalan dengan pernyataan Mardikanto, 1990:

Pada umumnya, perempuan yang berperan aktif dalam kehidupan ekonomi rumah tangganya, diharapkan memegang tanggung jawab yang besar di dalam keluarganya. Jika seorang ibu memiliki peran ganda baik sebagai ibu rumah tangga dan harus melakukan pekerjaan nafkah, akan terjadi perubahan antara tanggung jawab mengasuh anak dan tanggung jawab ekonomi rumah tangga yang lain yang berkaitan dengan pekerjaan nafkah di pasar kerja". (hlm. 57)

Walaupun perempuan pengrajin batik ini berperan aktif dalam bekerja, mereka juga tetap memegang tanggung jawab mereka untuk melakukan tugas rumah tangga salah satunya adalah mengasuh anak salah satunya terkadang mereka mengantarkan anak ke sekolah. pada hari libur perempuan pengrajin batik ini tetap meluangkan waktunya.

Dalam hal ini anak merasakan dampak ketika orang tua mereka terutama ibunya bekerja di luar rumah. Dampak positif ketika ibu mereka bekerja adalah anak dituntut untuk lebih mandiri dengan sering membantu pekerjaan rumah. Setiap paginya mereka berangkat ke sekolah diantar oleh ibu kadang juga mereka tidak diantar. Kemudian saat ibu mereka bekerja anak tersebut ikut dalam membantu pekerjaan rumahnya yaitu dengan menyapu, mencuci piring dan lain sebagainya. $\mathrm{Hal}$ ini yang mengharuskan anak perempuan pengrajin batik ini di tuntut untuk lebih mandiri dalam menjalankan apapun. Selain itu dampak negatif yang dirasakan oleh anak perempuan pengrajin batik ini adalah berkurangnya waktu yang dimiliki oleh ibu kepada anaknya. Waktu yang dimiliki perempuan pengrajin batik ini untuk anaknya adalah saat mereka selesai bekerja itupun jika perempuan tidak merasa lelah dan waktu yang dimilikinya saat 
perempuan pengrajin batik ini libur. Pada jawaban mengenai dampak negatif terhadap anak ini merupakan fungsi laten yaitu fungsi yang tersembunyi, pernyataan ini sesuai dengan Merton (dalam Poloma, 2013, hlm. 39) menyatakan bahwa "...fungsi laten merupakan fungsi yang tersembunyi". Peran tersembunyi yang dirasakan oleh perempuan pengrajin batik ini adalah berkurangnya waktu untuk bermain bersama anak karena para perempuan pengrajin batik ini setiap harinya bekerja dari pagi hingga sore hari sehingga waktu mereka dengan keluarga khususnya untuk anak berkurang, maka dari itu mereka memanfaatkan waktu libur mereka untuk bermain bersama anak. Waktu yang dimiliki perempuan pengrajin batik ini untuk anaknya adalah saat mereka selesai bekerja itupun jika perempuan tidak merasa lelah dan waktu yang dimilikinya saat perempuan pengrajin batik ini libur. Hari libur yang dimiliki oleh perempuan pengrajin batik ini adalah saat hari minggu. Pada hari minggu itulah perempuan pengrajin batik ini memanfaatkan waktunya untuk mengobrol bersama dan juga mengajak anak untuk bermain.

\section{SIMPULAN}

Gambaran umum peran ganda perempuan ini adalah semua perempuan pengrajin batik yang sudah menikah memiliki peran lebih dari satu yaitu peran di keluarga sebagai ibu rumah tangga dengan menjadi ibu yang baik bagi anakanaknya dan isteri yang baik bagi suaminya serta mengurus segala urusan rumah tangga dengan menjalankan tugasnya seperti memasak, mencuci dan menyiapkan keperluan suami serta anak-anaknya. Peran yang kedua yaitu peran sebagai pekerja dengan menjalankan perannya sesuai profesi yang dimilikinya yaitu sebagai perempuan pengrajin batik. Perempuan sebagai pengrajin batik dengan menjalankan tugasnya secara baik dan telaten serta menaati segala peraturan yang telah ada. Peran yang ketiga yaitu peran sebagai anggota masyarakat, dalam menjalankan peran tersebut, para perempuan pengrajin batik menjadi anggota PKK dan anggota majelis ta'lim dengan mengikuti kegiatan-kegiatan dalam organisasi tersebut.

Perempuan yang memiliki peran ganda akan merasakan beberapa kendala dalam menjalankan semua perannya. Kendala yang pertama terdapat dari dalam diri perempuan itu sendiri yaitu keterbatasan tenaga yang menyebabkan lelah fisik dan mental, serta adanya kejenuhan dalam melakukan semua perannya sehingga membuat mereka malas dalam menjalankan semua peran. Kendala yang berasal dari luar diri mereka adalah kekhawatiran hubungan yang kurang harmonis dengan anak dan suami, pengasuhan anak akan terabaikan karena waktu yang dimiliki terbatas, pengelolaan rumah tangga yang terabaikan, dan jika perempuan pengrajin batik melakukan kesalahan otomatis akan mendapatkan sanksi, sanksinya yaitu perempuan pengrajin batik ini akan 
kehilangan pekerjaan sehingga dapat menyebabkan mereka kehilangan mata pencahariannya.

Dampak yang dirasakan oleh perempuan pengrajin batik ini dalam melakukan semua perannya yaitu berdampak positif dengan adanya kepuasan dalam diri karena fungsi dalam keluarga dapat terpenuhi. Saat perempuan bekerja, mereka akan mendapatkan upah sehingga dapat membantu perekonomian keluarga, dan meningkatkan keterampilan dalam membatik. Dampak peran perempuan pengrajin batik sebagai anggota masyarakat yaitu dapat memperluas lingkungan sosial, menjalin silahturahmi, menambah pengetahuan mengenai agama ketika mengikuti kegiatan pengajian, lebih mendekatkan diri dengan sang pencipta, dan dapat memetik hikmah dengan mendengarkan ceramah dalam kegiatan pengajian. Dampak negatifnya yaitu mereka merasa lelah dengan semua perannya, berkurangnya waktu untuk bersama anak dan suami yang disebabkan oleh keterbatasan waktu dan tenaga yang dimiliki. Selain dampak terhadap perempuan, anggota keluarga juga merasakan dampaknya. Dampak positif yang dirasakan oleh suami yaitu dengan perempuan ikut bekerja dapat membantu perekonomian keluarga serta adanya kerja sama antara suami dan isteri dalam menyelesaikan tugas rumah tangga dan mengurus anak. Dampak negatifnya, alokasi waktu untuk berhubungan antara suami dan isteri menjadi berkurang. Selanjutnya anak merasakan dampak positifnya yaitu anak diberi kepercayaan oleh orang tua untuk menjaga dirinya sendiri dan juga anak lebih mandiri, serta dampak negatifnya adalah berkurangnya waktu untuk bermain dengan ibu.

\section{DAFTAR RUJUKAN}

\section{Buku:}

Mardikanto, T.(1990) Wanita dan Keluarga. Surakarta: PT Tri Tunggal Tata Fajar.

Poloma. M.M. (2013). Sosiologi kontemporer. Jakarta: PT. RajaGrafindo Persada.

\section{Jurnal:}

Indriyani, A. (2009). Pengaruh konflik peran ganda dan Stress kerja terhadap kinerja Perawat wanita rumah sakit. [Jurnal]. Universitas Diponegoro.

Kusumawati, Y. (2012). Peran Perempuan Pemetik Teh. [Jurnal]. Universitas Negeri Semarang. Vol. 04, No. 02.

Othman, M. B. (2015). Role of women in achieving shared prosperity: An impact study of Islamic microfinance in Malaysia. [Jurnal].

Salaa, Jeiske. (2015). Peran Ganda Ibu Rumah Tangga dalam Meningkatkan Ekonomi Keluarga di Desa Tarohan Kecamatan Beo Kabupaten Kepulauan Talaud. Jurnal Holistik. Vol. 15, No. 08.

Siregar, M. (2007). Keterlibatan ibu bekerja Dalam perkembangan pendidikan anak. [Jurnal]. 
Sosietas Vol. 6 No.2, September 2016

Universitas Sumatera Utara. Vol. 02, No. 01. 